\title{
Pharmaceutical Fraud: Off-Label Marketing of Drugs in the
}

\author{
United States, 2009-2016 \\ Zac Greenman $^{1 *} \&$ Dr. Cindy Greenman, CFE ${ }^{1}$ \\ ${ }^{1}$ Embry-Riddle Aeronautical University-Prescott Campus, Prescott, Arizona, United States \\ *Zac Greenman, E-mail: greenman.zac@gmail.com
}

Received: October 6, 2017

Accepted: October 16, 2017

Online Published: October 25, 2017

doi:10.22158/rem.v2n5p198

URL: http://dx.doi.org/10.22158/rem.v2n5p198

\begin{abstract}
The Federal False Claims Act (FCA) is a law that enforces liability on companies (or persons) who defraud government programs. Its original purpose was to combat fraud against the United States Army during the Civil War. Under the original FCA private citizens could file a lawsuit on behalf of the government and receive a percentage of the recovery.

The False Claims Act has been somewhat effective in combating fraudulent claims by pharmaceutical manufacturers. According to the Department of Justice (DOJ) website over $\$ 19$ billion has been collected from the pharmaceutical companies for various violations of the FCA including billing, marketing and pricing schemes.

Our research focused on all cases involving pharmaceutical manufacturers through False Claims Act (FCA) violations, specifically the Off-Label Marketing of Drugs. There were 22 cases in the eight years that our research covered. The total amount collected in the eight years was over \$14.1 billion (Table). This was only those cases related to Off-Label Marketing. One company, Pfizer Corp., was involved in 4 of the 22 cases totaling $\$ 3,448$ million over a five-year period. Johnson \& Johnson Corp. settled 3 cases for a total of \$2,299 million.
\end{abstract}

\section{Keywords}

federal false claims act, pharmacentical fraud, off-label marketing, fraud, pharma fraud

\section{Introduction}

The Federal False Claims Act (FCA) is a law that enforces liability on companies (or persons) who defraud government programs. The FCA is also known as "Lincoln Law" due to the fact that it was our $16^{\text {th }}$ President who signed this law in 1863. Its original purpose was to combat fraud against the United States Army during the Civil War. Under the original FCA private citizens could file a lawsuit on behalf of the government and receive a percentage of the recovery. This is known as "qui tam", referring to the Latin expression "qui tam pro domino rage quam pro se ipso in have parte sequitur" which means, 
"who sues on behalf of the King as well as for himself". This was part of the FCA legislation to encourage citizens to report wrongdoing against the government (Note 1).

Over the last 150 years, Congress has amended the FCA on three occasions. In 1986, special incentives for whistle blowing insiders were added. Up until the 1990s, the FCA had mainly been used against defense contractors. Health care fraud then became an emphasis. This led to the amendment of 2009, the "Fraud Enforcement Recovery Act". The 2010 changes were specific to health care under the "Patient Protection and Affordable Care Act".

The False Claims Act has been somewhat effective in combating fraudulent claims by pharmaceutical manufacturers. With the whistleblower provision being implemented in 2009, this has increased the cases being brought under the FCA. According to the Department of Justice (DOJ) website over $\$ 19$ billion has been collected from the pharmaceutical companies for various violations of the FCA including billing, marketing and pricing schemes (Note 2). It is believed, however, that this is simply the insignificant portion of something much, much bigger. Some of the more common schemes that the drug companies have frequently utilized that may violate the FCA include:

-Off-label Marketing of Drugs: the use of pharmaceutical drugs for unapproved purposes, dosages, ages, etc. Pharmaceuticals in the United States are highly regulated by the Food and Drug Administration (FDA). The drugs must be rigorously tested before approval and the FDA determines exactly which medical conditions, ages, and dosages the drug may be used to treat. Drug companies that promote their drugs to physicians for an off-label or an unapproved use are in violation of federal law (Note 3). -Illegal Kickbacks: a common scheme that the pharmaceutical companies have been found guilty of is providing payments or other financial incentives to healthcare providers in order to persuade them to prescribe their drugs to patients. Also, kickbacks have been known to be paid to the insurance companies in order to have their drugs listed as those "preferred" to be prescribed to the insurance coverage.

-Inflated Pricing of Pharmaceuticals: one of the most common schemes used by pharmaceutical companies is inflating the prices of their drugs, or reporting to the government what the average price for which the drug wholesalers sell the specific drugs to their customers. By reporting a higher average price, this increases how much the Medicare and Medicaid programs must pay for those particular drugs (Note 4).

\section{Method}

Our research focused on all cases involving pharmaceutical manufacturers through False Claims Act (FCA) violations, specifically the Off-Label Marketing of Drugs. This law allows for private citizens to file antifraud actions on behalf of the government and this imposes liability of up to triple damages along with civil penalties for each claim, with the citizens receiving a percentage of the reclamation. We used meta-analysis to gather information from previous research. We also compiled our own data on the total settlement as well as the amount received by the qui tam relators. Data was collected from 
Lexis/Nexis and Department of Justice websites. Financial recoveries of less than $\$ 5$ million were excluded.

\section{Result}

There were 22 cases in the eight years that our research covered. The total amount collected in the eight years was over $\$ 14.1$ billion (Table 1). This was only those cases related to Off-label marketing. One company, Pfizer Corp., was involved in 4 of the 22 cases totaling $\$ 3,448$ million over a five-year period. Johnson \& Johnson Corp. settled 3 cases for a total of $\$ 2,299$ million.

Although only involved in one of the 22 cases we discovered, the largest healthcare fraud settlement in United States history is the $\$ 3$ billion paid out by Glaxo Smith Kline (GSK). They settled the suit when they pled guilty to the off-label marketing of two different drugs for uses that had they had not been approved. The pharmaceutical giant admitted that they had held certain information back from the Federal Drug Administration (FDA) and they had made unsupported claims over certain drugs. Plus, GSK admitted to paying kickbacks to doctors to prescribe and promote their drugs for the off-label purposes. The settlement covered both criminal and civil fines with the federal and state governments. GlaxoSmithKline paid their $\$ 3$ billion fine out of their cash reserves immediately upon learning of their penalty (Note 5). From 1991 through 2015, GSK paid financial penalties of $\$ 7.9$ billion to federal and state governments. This is double what any other pharmaceutical company has paid. 


\begin{tabular}{|c|c|c|c|c|c|c|}
\hline \multicolumn{7}{|c|}{ Settled Federal False Claims Act Cases Involving Pharmaceutical Product Manufacturers (2009-2016) } \\
\hline \multirow[b]{2}{*}{ Company } & \multirow[b]{2}{*}{ Headquarters } & \multirow[b]{2}{*}{ Year } & \multicolumn{2}{|c|}{ All $\$$ amounts in Millions } & \multirow[b]{2}{*}{ Violation } & \multirow[b]{2}{*}{ Product (type/FDA a pproved us age) } \\
\hline & & & Total Recovered & $\begin{array}{c}\text { Amount Recovered by } \\
\text { Qui Tam Filers }\end{array}$ & & \\
\hline Eli Lilly and Company & $\begin{array}{l}\text { Indianapolis, Indiana, } \\
\text { United States }\end{array}$ & 2009 & 1,400 & 438 & Off-label promotion & $\begin{array}{c}\text { Zyprexa (antipsychotic, for schizophrenia and } \\
\text { bipolar disoder) }\end{array}$ \\
\hline Pfizer & $\begin{array}{l}\text { New York, New York, } \\
\text { United States }\end{array}$ & 2009 & 2,900 & 102 & Off-label promotion & $\begin{array}{l}\text { Bextra (NSAID), Geodon (anti-psychotic for } \\
\text { Schitzophrenia/acute mania/mixed bipolar } \\
\text { states), Zyvox (antibiotic), and Lyrica (for } \\
\text { epilepsy, neuropathic pain, fibromialgia, and } \\
\text { general anxiety disorder) }\end{array}$ \\
\hline Pfizer (Alpharma) & $\begin{array}{c}\text { Bristol, Tennessee, United } \\
\text { States }\end{array}$ & 2010 & 42.5 & 5.33 & Off-label promotion & Kadian (extended-release morphine) \\
\hline AstraZeneca & Cambridge, England & 2010 & 520 & N/A & Off-label promotion & $\begin{array}{c}\text { Seroquel (anti-psychotic for schizophrenia, } \\
\text { bipolar disorder, and major depressive } \\
\text { disorder) }\end{array}$ \\
\hline $\begin{array}{l}\text { Johnson \& Johnson ( Ortho- } \\
\text { McNeil Pharmaceutical and } \\
\text { Ortho-McNeil-Janssen) }\end{array}$ & $\begin{array}{l}\text { Raritan, New Jersey, } \\
\text { United States }\end{array}$ & 2010 & 81 & $\$$ & Off-label promotion & Topamax (anticonvulsant/antiepilepsy) \\
\hline Novartis International AG & Basel, Switzerland & 2010 & 72.5 & 7.8 & Off-label promotion & Tobi (antibiotic) \\
\hline Allergan, PLC & $\begin{array}{l}\text { Dublin, Ireland, and } \\
\text { Parsippany-Troy Hills, New } \\
\text { Jersey, United States. }\end{array}$ & 2010 & 600 & 37.8 & Off-label promotion & $\begin{array}{c}\text { Botox (neurotoxic protein, for headaches, neck } \\
\text { pain, cervical dystonia, and axillary } \\
\text { hyperhidrosis) }\end{array}$ \\
\hline Novartis International AG & Basel, Switzerland & 2010 & 422.5 & $\$$ & Off-label promotion/kickbacks & $\begin{array}{l}\text { Trileptal (anticonvulsant, for treatment of } \\
\text { partial seizures associated with epilepsy) }\end{array}$ \\
\hline Forest Laboratories, Inc. & $\begin{array}{l}\text { New York, New York, } \\
\text { United States }\end{array}$ & 2010 & 313 & $\$$ & $\begin{array}{l}\text { Off-label } \\
\text { promotion/distribution of an } \\
\text { unapproved drug (Levothroid) }\end{array}$ & $\begin{array}{l}\text { Levothroid (thyroid hormone), Celexa } \\
\text { (SSRI/antidepressant, for major depression), } \\
\text { and Lexapro (SSRI/antidepressant, for major } \\
\text { depression and generalized anxiety disorder) }\end{array}$ \\
\hline $\begin{array}{c}\text { Élan Corporation, PLC (acquired } \\
\text { by Perrigo Co. in 2013) }\end{array}$ & Dublin, Ireland & 2010 & 214.5 & $\$$ & Off-label promotion & $\begin{array}{l}\text { Zonegran (anticonvulsant, for Parkinson's } \\
\text { disease, partial-onset seizures, Lennox- } \\
\text { Gastaut syndrome, and other seizures) }\end{array}$ \\
\hline $\begin{array}{l}\text { Abbott Laboratories (Kos } \\
\text { Pharmaceuticals) }\end{array}$ & $\begin{array}{l}\text { Lake Bluff, Illinois, United } \\
\text { States }\end{array}$ & 2010 & 41 & 6.4 & Off-label promotion/kickbacks & $\begin{array}{l}\text { Advicor (Niacin \& Lovastatin mix, for } \\
\text { dyslipidemia and Niaspan (Niacin, for } \\
\text { cardiovascular disease, etc.) }\end{array}$ \\
\hline UCB & Brussels, Belgium & 2011 & 34 & 2.8 & Off-label promotion & Keppra (For epilepsy) \\
\hline Pfizer & $\begin{array}{l}\text { New York, New York, } \\
\text { United States }\end{array}$ & 2011 & 14.5 & 3.3 & Off-label promotion & $\begin{array}{c}\text { Detrol (antimuscarinic, for urinary } \\
\text { incontinence) }\end{array}$ \\
\hline Abbott Laboratories & $\begin{array}{l}\text { Lake Bluff, Illinois, United } \\
\text { States }\end{array}$ & 2012 & 1,500 & 84 & Off-label promotion & $\begin{array}{l}\text { Depakote (For epilepsy, bipolar disorder, and } \\
\text { prevention of migraines) }\end{array}$ \\
\hline GlaxoSmithKline & Brentford, United Kingdom & 2012 & 3,000 & $\$$ & Off-label promotion/kickbacks & Paxil, wellbutrin, avandia and other drugs. \\
\hline Pfizer (Wyeth Pharmaceuticals) & $\begin{array}{l}\text { New York, New York, } \\
\text { United States }\end{array}$ & 2013 & 490.9 & N/A & Off-label promotion & $\begin{array}{l}\text { Rapamune (immunosupressant, for coronary } \\
\text { stents and prevention of organ transplant } \\
\text { rejections) }\end{array}$ \\
\hline Johnson \& Johnson & $\begin{array}{l}\text { New Brunswick, New } \\
\text { Jersey, United States }\end{array}$ & 2013 & 2,200 & 167.7 & Off-label promotion/kickbacks & $\begin{array}{l}\text { Risperdal (antipsychotic, for schizophrenia, } \\
\text { bipolar disorder, and irritability in Autistic } \\
\text { individuals), Invega (dopamine } \\
\text { antagonist/antipsychotic, for bipolar disorder, } \\
\text { schizophrenia, and schizoacffective disorder) } \\
\text { and Natrecor (cardiovascular amino acid } \\
\text { recombinant, for types of congestive heart } \\
\text { failure) }\end{array}$ \\
\hline CareFusion & $\begin{array}{l}\text { San Diego, California, } \\
\text { United States }\end{array}$ & 2014 & 40.1 & 3.26 & Off-label promotion/kickbacks & $\begin{array}{c}\text { Chlora Prep (surgical disinfectant \& antiseptic, } \\
\text { for skin \& surgical instrument } \\
\text { disinfection/sterilization before surgical } \\
\text { application) }\end{array}$ \\
\hline $\begin{array}{l}\text { Endo International, PLC (Endo } \\
\text { Pharmaceuticals) }\end{array}$ & $\begin{array}{l}\text { Dublin, Ireland, and } \\
\text { Malvern, Pennsylvania, } \\
\text { United States }\end{array}$ & 2014 & 192.7 & $\mathrm{~N} / \mathrm{A}$ & Off-label promotion/kickbacks & $\begin{array}{l}\text { Lidoderm (Lidocaine/local anaesthetic, for } \\
\text { numbing) }\end{array}$ \\
\hline Johnson \& Johnson (Acclarent) & $\begin{array}{l}\text { New Brunswick, New } \\
\text { Jersey, United States }\end{array}$ & 2016 & 18 & N/A & $\begin{array}{l}\text { Off-label } \\
\text { promotion/misbranding }\end{array}$ & $\begin{array}{l}\text { Sinus Spacer Product (distributed as a drug } \\
\text { delivery method after FDA denial to expand } \\
\text { the product's approved usages) }\end{array}$ \\
\hline BTG PLC (Biocompatibles Inc.) & London, United Kingdom & 2016 & 36 & N/A & $\begin{array}{c}\text { Off-label } \\
\text { promotion/misbranding }\end{array}$ & $\begin{array}{l}\text { LC Bead (embolization device, to be inserted } \\
\text { into blood vessels to restrict bloodflow to } \\
\text { tumors) }\end{array}$ \\
\hline Bristol-Myers Squibb Company & $\begin{array}{c}\text { New York, New York, } \\
\text { United States }\end{array}$ & 2016 & 19.5 & N/A & $\begin{array}{c}\text { Off-label } \\
\text { promotion/misbranding } \\
\end{array}$ & $\begin{array}{c}\text { Abilify (antipsychotic, for schizophrenia and } \\
\text { bipolar disorder) }\end{array}$ \\
\hline & & Totals: & $14,152.70$ & 950.39 & & \\
\hline & & & 14.1 billion & 950 million & & \\
\hline
\end{tabular}

Figure 1. Settled False Claims Act Cases Involving Pharmaceutical Product Manufacturers 
The United States pharmaceutical industry was worth an estimated \$446 billion in 2016. The United States holds over 45 percent of the world's pharmaceutical marketplace. Six out of the top ten drug companies in the world are from the U.S. It is said to be the "world's most important national market" (Note 6). The largest pharmaceutical company in the United States in 2015 was Pfizer Corporation. Their revenue in 2015 was almost \$49 billion (in November of 2015 Pfizer merged with an Irish company and moved their headquarters to Ireland, thus lowering their tax rate by almost half) (Note 7).

\section{Discussion}

Since 1996, \$19 billion has been collected from pharmaceutical companies for various pricing, billing and marketing schemes that are in violation of the Federal and State False Claims Acts. So, in relation to the 2008 bank bailout, the American banks were said to be "too big to fail". But, the bank bailout of 2008 was only $\$ 700$ billion (Note 8 ). The pharmaceutical companies just keep getting bought up and are currently in the "too big to fail" category in the United States. Once one starts to go down, it's just bought up by another: similar to how banks were in 2008. But, remember how the bank collapse ruined the United States economy. Stocks plummeted, mortgages became too expensive, peoples' money became worthless. Think of how a failure in the prescription medication industry would affect the country. People already cannot afford their medications, which they desperately need. In 2015, Martin Shkreli raised the price of a malaria medication by a factor of 56 , making it almost $\$ 700 /$ pill. When pricing fraud like this occurs, it's not a matter of just the economy. People die when they cannot afford their medication. It is becoming all too common for people to have to choose between buying food or buying their medication.

As a fraudulent industry with sales above $\$ 1$ trillion in 2014 (\$450 billion in the U.S. alone), the pharmaceutical industry is notorious for hiring former government employees in an effort to farm their political connections to gain political standing. The trade group PhRMA actually has 50+ former and current employees who used to work in the government. These include 36 former Congress members, 13 who used to work for federal agencies, 12 who were a part of a congressional committee, 2 formerly worked for the White House, and one who was employed by the court system (Note 9). These political connections give the pharmaceutical industry a significant advantage over other industries. Pharmaceutical companies are already protected from free-market competition. That's a perk that only U.S. pharmaceutical companies have (as well as marketing directly to doctors and consumers, those methods aren't typical in European countries).

Pharmaceutical companies need to be held to a higher standard in the United States. They go widely unregulated and while it seems as though they're bleeding money from all the settlements they expense out, the amount of fraud inherent to keep the companies alive is blatantly apparent and needs to be cracked down on before it becomes paralleled with the 2008 housing crisis. The United States produces and purchases more than $47 \%$ of the world's pharmaceuticals, which is far more than any other country on the planet. The fact that they are not subjected to free-market competition only makes it easier for 
the bad guys to get richer while everyone else gets sicker (Note 10).

The high costs of pharmaceuticals in the United States are not only the fault of the companies, however. Just recently, July 2017, the Attorney General announced that charges were being filed against 412 doctors, nurses and pharmacists in what he called, "the largest health care fraud enforcement operation in U.S. history" (Johnson). In this particular case, one doctor has been accused of writing more than 12,000 prescriptions for opioids. That is the equivalent to more than 2 million illegal doses. Other doctors have been accused of writing more prescriptions for opioids than an entire hospital would normally write. This inflated demand, leads to inflated costs. Abuse of the expensive painkillers can then lead addicts to cheaper alternatives, mainly heroin. In this same case, a group of six Michigan doctors are accused of providing patients with unnecessary opioid prescriptions and then billing Medicare for $\$ 164$ million. Some of those same prescriptions ended up being resold on the streets to addicts (Note 11).

\section{Conclusion}

Our analysis has limitations, principally the absence of other FCA violations other than off-label marketing. Despite this, our analysis emphasizes that many of the larger pharmaceutical companies have been implicated in health care fraud cases, sometimes more than once. With the growth of the health care industry, investigations into the manufacturers of pharmaceutical drugs will continue to result in significant recoveries. Our research also raises concerns that despite these sizeable recoveries, industry wide changes are much needed (Note 12).

\section{References}

Amadeo, K. (2017, February 7). What is too big to fail? With examples of banks. Retrieved February 12, 2017, from https://www.thebalance.com/too-big-to-fail-3305617

BBC News. (2012, July). GlaxoSmithKline to Pay 43bn in US Drug Fraud Scandal. Retrieved from http://www.bbc.com/news/world-us-canada-18673220

Berg, \& Androphy. (n.d.). Overview of the FCA and Its Qui Tam Provisions. Retrieved from https://www.bafirm.com/practice-areas/qui-tam-litigation/overview/overview-of-the-fca-and-its-q ui-tam-provisions/

drugwatch.com. (2017). Manufacturers. Retrieved February 13, 2017, from https://www.drugwatch.com/manufacturer/

False Claims Act Resource Center. (2017). Pharmaceutical Fraud. Retrieved August 15, 2017, from https://www.falseclaimsact.com/common-types-of-fraud/pharmaceutical-fraud

Johnson, K. (2017, July 14). 412 Charged in \$1.3 Billion Opioid Fraud Takedown. USA Today.

Mole, B. (2015, November 23). With $\$ 160$ billion merger, Pfizer moves to Ireland and dodges taxes. $\begin{array}{llll}\text { Retrieved } & \text { August } & \text { 15, } & \text { from }\end{array}$ https://arstechnica.com/science/2015/11/with-160-billion-merger-pfizer-moves-to-ireland-and-dod 
ges-taxes/

Phillips, \& Cohen PPC. (2017). Off-label marketing, Medicare, Medicaid, and qui tam (whistleblower) lawsuits. Retrieved August 15, 2017, from https://www.phillipsandcohen.com/off-label-marketing/

Qureshi, Z., Sartor, O., Xirasagar, S., Liu, Y., \& Bennett, C. L. (2011). Pharmaceutical Fraud and Abuse in the United States, 1996-2010, 171(16), 1503-1506.

Statista. (2017). U.S. Pharmaceutical Industry-Statistics \& Facts. Retrieved March 4, 2017, from https://www.statista.com/topics/1719/pharmaceutical-industry/

US Department of Justice. (2013). HYPERLINK. Retrieved from http://www.justice.gov/civil/docs_forms/C-FRAUDS_FCA_Statistics.pdf

Vallverde, J. L. (2013, February 4). Corporate Responsibility and Pharmaceutical Fraud. Retrieved from http://content.iospress.com/articles/pharmaceuticals-policy-and-law/ppl00350

\section{Notes}

Note 1. Berg \& Androphy, 2017.

Note 2. Department of Justice (DOJ) website.

Note 3. Off-Label marketing, Medicare, Medicaid, and qui tam (whistleblower) lawsuits, 2017.

Note 4. False Claims Act Resource Center, 2017.

Note 5. BBC News, 2012.

Note 6. Statista, 2017.

Note 7. Mole, B., 2015

Note 8. Amadeo, February, 2017.

Note 9. Drugwatch.com, 2017.

Note 10.Vallverde, J., 2013.

Note 11. Johnson, 2017.

Note 12. Qureshi et al., 2011. 